\title{
Bimbingan Agama dalam Meningkatkan Pemahaman Ketauhidan Remaja
}

\author{
Nasep Khirzani ${ }^{*}$, Dudy Imanudin Effendi ${ }^{2}$, Abdul Mujib ${ }^{3}$ \\ 123Jurusan Bimbingan dan Konseling Islam, UIN Sunan Gunung Djati, Bandung \\ *Email: nasepbki@gmail.com
}

\begin{abstract}
ABSTRAK
Tujuan dari penelitian ini adalah untuk mengetahui proses bimbingan agama, tingkat pemahaman ketauhidan dan pengaruh bimbingan agama dalam meningkatkan pemahaman ketauhidan remaja yang dilakukan di pondok pesantren tanjung salam. Metode yang digunakan pada penelitian ini adalah menggunakan kualitatif, dengan teknik pengumpulan data menggunakan observasi, wawancara dan dokumentasi. Berdasarkan penelitian ini dapat disimpulkan bahwa tingkat pemahaman santri di ponpes tanjung salam yang meliputi pemahaman tentang dua kalimat syahadat, sifat-sifat Allah, dan rasul-Nya meningkat setelah mengikuti bimbingan agama berupa kajian kitab kuning (tijan ad-darory fi syarbil badjury). Pemahaman tersebut dibarengi dengan kesadaran untuk mengaplikasikannya diaplikasikan dalam kehidupan mereka.
\end{abstract}

Kata Kunci : bimbingan agama; pemahaman tauhid; remaja.

\begin{abstract}
The purpose of this study was to determine the process of religious guidance, to determine the level of understanding of monotheism and to determine the effect of religious guidance in improving the understanding of adolescent monotheism that were carried out in Tanjung Salam Islamic boarding school. The method used in this research is to use a type of research with qualitative methods, with data collection techniques using observation, interviews and documentation. Based on this research, it can be concluded that the level of understanding of students in the tanjung salam pesantren which includes understanding of the two sentences of shahada, the attributes of God, and His apostles increased after following religious guidance in the form of a study of the yellow book (tijan ad-darory fi syarbil badjury). This understanding is accompanied by an awareness to apply it to their lives.
\end{abstract}

Keywords: religion councelling; religion understanding; adolescents. 


\section{PENDAHULUAN}

Mempelajari tauhid merupakan hal pokok yang sudah menjadi keharusan bagi seseorang untuk mempelajarinya. Untuk itu, sudah menjadi keharusan pula bagi orang tua untuk mendahulukan penanaman tauhid semenjak dini kepada putra-putrinya. Sebagaimana ungkapan Ibnu Qayyim dalam kitab Tuhfat Al-Maudūd yang dikutip oleh Rahman bahwa dirahasiakan dilakukan ażan dan iqāmaĥ di telinga bayi yang baru lahir mengandung harapan yang optimis agar mula-mula suara yang terdengar oleh telinga bayi adalah seruan ażan yang mengandung makna keagungan dan kebesaran Allah serta syahādāt yang menjadi syarat utama bagi seorang yang masuk Islam. Hal yang sama dianjurkan pula agar yang bersangkutan dituntut untuk mengucapkan kalimat tauhid ini saat sedang meregang nyawa meninggalkan dunia yang fana ini (Rahman, $2000: 43$ ).

Tingginya angka kenakalan remaja di Indonesia cukup menghawatirkan. Menurut data Bio Statistik Universitas Gadjah Mada (UGM) Yogyakarta, lima provinsi di Indonesia yang memiliki angka kenakalan remaja yang tinggi adalah Provinsi Sumatera Utara, DKI Jakarta, Jawa Barat, Jawa Tengah, dan Jawa Timur. Serta dari hasil asesmen yang telah dilakukan oleh PMI didapat sebuah kesimpulan bahwa lebih dari 65\% remaja memiliki masalah di keluarga, seperti masalah keuangan, masalah perceraian, dan anggota keluarga meninggal. Hal tersebut berdampak pada banyaknya permasalahan yang timbul, seperti penyalahgunaan alkohol, obat-obatan dan senjata, kekerasan, dan lain-lain (Setiawan, 2014).

Pondok pesantren pada dasarnya adalah lembaga pendidikan Islam yang dilaksanakan dengan sistem asrama (pondok), kiai atau mushalla sebagai pusat lembaganya. Lembaga ini merupakan salah satu bentuk kebudayaan asli pendidikan nasional, sebab lembaga ini telah lama hidup dan tumbuh ditengahtengah masyarakat Indonesia yang tersebar diseluruh tanah air dan dikenal dalam kisah serta cerita rakyat Indonesia khususnya di pulau Jawa (Haryanto, 2012 : 39).

Sejak awal kelahirannya, pesantren tumbuh, berkembang dan tersebar di berbagai pedesaan. Keberadaan pesantren sebagai lembaga keislaman yang sangat kental dengan karakteristik Indonesia ini memiliki nilai-nilai strategis dalam pengembangan masyarakat Indoesia. Realitas menunjukan pada satu sisi sebagian besar penduduk Indonesia terdiri dari umat Islam, dan pada sisi lain mayoritas dari mereka tinggal di pedesaan.

Berdasarkan realita tersebut, pesantren sampai saat ini memiliki pengaruh cukup kuat pada hampir seluruh aspek kehidupan di kalangan masyarakat muslim pedesaan yang taat (A"la, 2006:1). 
Salah satu upaya seorang ulama dalam mempersiapkan generasi muda yang beriman ialah dengan bagaimana ia mengajak generasi muda tersebut untuk belajar mengenal keesaan Allah SW'T melalui pendidikan tauhid melalui bimbingan keagamaan Islam karena dengan dibekali tentang ketauhidan diharapkan setiap generasi muda akan lebih mengenali Allah SW'T sebagai Tuhan yang Esa.

Pondok pesantren Tanjung Salam merupakan satu-satunya lembaga pendidikan Islam yang ada di Kampung Ciseupan Desa Panyocokan Kecamatan Ciwidey Kabupaten Bandung. Pondok pesantren ini banyak mempelajari berbagai macam kitab salah satunya adalah Syu'ubul Iman yang membahas tentang ketauhidan dan kitab-kitab klasik lainnya seperti Tijanu Durori karya Syaikh Ibrahim Al-Bajuri, dan kitab Jawahirul Kalamiyah karya Syaikh Thahir bin Shalih Al-Jazair dengan metode penyampaiannya menggunakan bimbingan keagamaan (religious guidance).penerapan metode tersebut diharapkan agar senantiasa dapat mempermudah dalam membantu para santri dalam memahami pembelajaran tauhid serta senantiasa memberikan ikatan yang kuat dalam interaksi antara kiai dan santri agar lebih terjalin dengan baik.

Selain itu di Pondok pesantren Tanjung Salam memiliki santri yang terdiri dari santri yang masih berusia remaja dan selain belajar mengaji disana juga ada metode penerapan dari pelajaran yang mereka dapat dengan kehidupan sehari-hari yaitu apa yang mereka pelajari harus diterapkan dalam kehidupan sehari-hari dan perkembangan mereka itu selalu dipantau oleh pihak pengelola pesantren.

\section{LANDASAN TEORITIS}

Setiap individu memiliki masalah yang berbeda-beda sesuai dengan tingkatan kehidupannya. Tapi, masing-masing individu tidak memiliki kemampuan yang sama rata dalam memecahkan masalahnya. Bimbingan dan konseling adalah salah satu layanan bantuan untuk orang yang membutuhkan bantuan (konseli) yang bermasalah agar dapat lebih mandiri dan berkembang secara optimal dalam hubungan pribadi, sosial, belajar, karir, melalui berbagai jenis layanan dan kegiatan pendukung atas dasar norma-norma yang berlaku. Tujuan bimbingan dan konseling yaitu untuk membantu memandirikan setiap konseli dalam mengembangkan setiap potensi-potensi individu secara lebih optimal (Hikmawati, 2012: 64).

Menurut Kartini (1986: 25) remaja adalah suatu periode transisi dari masa awal anak-anak hingga masa awal dewasa yang dimasuki pada usia kira-kira 10 hingga 12 tahun dan berakhir pada usia 18 tahun hingga 22 tahun. Masa remaja bermula pada perubahan fisik yang cepat pertambahan berat dan tinggi badan yang derastis, perubahan bentuk tubuh dan perkembangan karakteristik seksual seperti pembesaran buah dada, perkembangan pinggang dan kumis, dan dalamnya suara. 
N. Khirzani., D. I. Effendi., A. Mujib.

Pada perkembangan ini pencapaian kemandirian dan identitas sangat menonjol (pemikiran semakin logis, abstrak, dan idealistis) dan semakin banyak menghabiskan waktu di luar keluarga.

Bagi kebanyakan orang, membuat janji lalu menemui seorang konselor bukan merupakan sesuatu yang mudah. Meski mulai banyak perubahan sikap yang terjadi, banyak orang masih beranggapan bahwa mencari bantuan dari luar untuk mengatasi problem diri sendiri adalah tanda kelemahan seseorang. Kondisi ini memepersulit mereka yang memiliki tanggung jawab kerja yang besar untuk datang mencari bantuan konseling. Orang-orang sering berpandangan bahwa jika mereka mengakui bahwa mencari bantuan seorang konselor, rekan-rekan mereka akan berfikir bahwa mereka lemah dan tidak mampu mengemban tanggung jawab. Karena itu, banyak orang yang enggan mencari bantuan lewat konseling kecuali kalau kondisi emosional mereka sudah sangat terganggu sehingga kemampuan untuk menangani tanggung jawab sehari-hari akan terhambat dan mereka tidak bisa lagi menyembuynyikan penderitaan dan tekanan emosi dari orang-orang di sekitar merkea (Geldard dan Geldard, 2011: 12).

Jika kita perhatikan sebuah fakta bahwa umumnya seorang konseli datang menemui konselor dengan membawa kondisi kecemasan dan tekanan jiwa yang tinggi, maka kita harus berasumsi bahwa tujuan utama dari konseling adalah membantu mereka merasa lebih baik untuk jangka pendek saja tidak akan cukup. Tidak akan ada gunanya seorang konseli merasa lebih baik dalam waktu yang sebentar saja, tetapi kemudian ia harus kembali ke kondisi tekanan emosi sebelumnya yang tidak menyenangkan. Karena itu tujuan utama proses bimbingan dan konseling adalah menolong konseli untuk dapat berubah. Konseli memerlukan perubahan dalam cara berpikir dan/atau mereka akan mengulangi pola pikir dan perilaku yang mengarah pada konsekuensi negatif bagi mereka (Geldard dan Geldard, 2011: 13).

Tujuan bimbingan dan konseling pada umumnya sama bagi siapapun termasuk bagi remaja. Ada beberapa tujuan baik secara eksplisit atau implisit dari tujuan konseling menurut para konselor : (1) Pemahaman, adanya pemahaman terhadap akar dan perkembangan kesulitan emosional, mengarah pada peningkatan kapasistas untuk lebih memilih kontrol rasional ketimbang perasaan dan tindakan. (2) Berhubungan dengan orang lain, menjadi lebih mampu membentuk dan mempertahankan hubungan yang bermakna dan memuaskan dengan orang lain seperti halnya dalam keluarga dan di tempat kerja. (3) Kesadaran diri, agar menjadi lebih peka terhadap pemikiran dan perasaan yang selama ini ditahan atau ditolak, atau mengembangkan perasaan yang lebih akurat berkenaan dengan bagaimana penerimaan orang lain terhadap diri. (4) Penerimaan diri, pengembangan sikap positif terhadap diri, yang ditandai oleh kemampuan menjelaskan pengalaman yang selalu menjadi subjek kritik dan penolakan. (5) 
Aktualisasi diri atau individuasi, pergerakan ke arah pemenuhan potensi atau penerimaan integrasi bagian diri yang sebelumnya saling bertentangan. (6) Pencerahan, membantu seorang konseli mencapai kondisi spiritual yang lebih tinggi. (7) Pemecahan masalah, menemukan pemecahan masalah tertentu yang tidak bisa dipecahkan oleh konseli seorang diri. Menuntut kompetensi umum dalam pemecahan masalah. (8) Pendidikan psikologi, membuat konseli mampu menangkap ide dan teknik untuk memahami dan mengontrol tingkah laku. 9) Memeiliki keterampilan sosial, konseli mempelajari dan menguasai keterampilan sosial interpersonal seperti mempertahankan kontak mata, tidak menyela pembicaraan, asertif, ataupengendalian kemarahan. Dan 10) Reproduksi dan aksi sosial, menginspirasi ke dalam diri seseorang hasrat dan kapasitas untuk peduli terhadap orang lain, membagi pengetahuan, dan mengkontribusikan kebaikan bersama (collective good) melalui kesepakatan politik dan kerja komunitas (McLeod, 2010: 13-14).

Sementara itu, untuk mencapai tujuan-tujuan tersebut, Hikmawati (2012: 66) mengemukakan bahwa di dalam prosesnya seorang konseli harus mendapatkan kesempatan untuk : (1) Mengenal dan memahami potensi, kekuatan, dan tugas-tugas perkembangannya; (2) Mengenal dan memahami potensi dan peluang yang ada di lingkungannya; (3) Mengenal dan menentukan tujuan dan rencana hidupnya serta rencana pencapaian tujuan tersebut; (4) Memahami dan mengatasi kesulitan-kesulitan sendiri; (5) Menggunakan kemampuannya untuk kepentingan dirinya dan kepentingan masyarakat; (6) Menyesuaikan diri dengan keadaan dan tuntutan dari lingkungannya; dan (7) Mengembangkan segala potensi dan kekuatan yang dimilikinya secara optimal.

\section{HASIL DAN PEMBAHASAN}

Pondok Pesantren Tanjung Salam merupakan lembaga yang bergerak dalam bidang pembinaan dan pendidikan agama Islam untuk mewujudkan manusia yang religius guna mencapai predikat manusia yang rabmatallil'alamien dihadapan Allah SWT. Pondok Pesantren Salaf Tanjung Salam bermula dari sebuah mesjid tua yang dibangun oleh masyarakat sekitar. Awalnya, di daerah tersebut terdapat seorang Ulama yang Waro' dan disegani oleh masyarakat bernama Mama Ali Afandi. Tidak sedikit dari masyarakat sekitar yang mengaji kepada beliau, bahkan tidak hanya penduduk sekitar saja, dari berbagai daerah pun banyak yang menuntut ilmu kepada beliau.

Setelah cukup lama mengabdi, banyak diantaranya murid-murid beliau yang berhasil. Banyak diantara murid beliau yang menjadi ulama di daerahnya masingmasing. Seperti halnya di daerah tersebut, lahirlah ulama penerus beliau yang bernama Kiyai Usman Baihaki. Pada tahun 1984, Kiyai Usman diberikan amanah untuk meneruskan perjuangan dalam menegakkan agama Islam setelah Mama Ali 
wafat. Pada saat itu, mesjid yang sekaligus digunakan untuk menuntut ilmu para santri dinamakan Al Fitroh yang berarti suci. Seiring berjalannya waktu jumlah santri di Mesjid Al Fitroh semakin banyak, lalu atas usulan dari sahabatnya sendiri untuk mendirikan pondok pesantren, maka Kiyai Usman pada tahun 1996 mendirikan pondok pesantren yang diberi nama Pondok Pesantren Tanjung Salam yang mempunyai arti agar tetap maju atau berkembang.

Selaras dengan arti dari namanya, Ponpes Tanjung Salam berkembang dari masa ke masa, para santrinya lebih dididik untuk memperdalam tilawah Quran dan kajian akhlak. Dan tidak sedikit Qari-qari Nasional lahir dari Ponpes Tanjung Salam. Awal mulanya, Ponpes Tanjung Salam terdiri dari dua bangunan, mesjid dan kobong putra hasil waqaf dari Bpk H. Salam pada tahun 1998, pada saat itu tidak menerima santri putri dikarenakan keterbatasan tempat.Namun seiring perkembangannya Ponpes ini pun menerima santri putri.

Pimpinan Ponpes Kiyai Usman dikenal oleh masyarakat dengan kesantunan dan kearifannya, beliau pun sayang kepada santrinya. Sehingga beliau disegani baik oleh santri maupun masyarakat sekitar. Namun, kesedihan harus dialami oleh para santri dan masyarakat sekitar, karena pada tahun 2006, Kiyai yang dikenal dengan kesantunan dan kearifan itu pun harus meninggalkan dunia yang fana ini.

Ketika pemimpin Ponpes Tanjung Salam meninggal dunia, Istri beliau yang saat ini menjabat sebagai Ibu pengasuh sempat akan menutup dan membubarkan para santri Tanjung Salam. Pada saat itu, ibu pengasuh merasa kalut dan merasa tidak ada lagi yang menyokong Ponpes Tanjung Salam. Akan tetapi pada akhirnya ada beberapa orang mahasiswa yang sedang KKN dari Fakultas Kedokteran menyarankan kepada ibu agar tidak membubarkan Ponpes ini. Dan untuk membantu dalam memajukan Ponpes ini, mereka memberikan bantuan berupa fasilitas-fasilitas yang dibutuhkan Ponpes Tanjung Salam seperti kitab-kitab dan lain sebagainya.

Setelah Kiyai Usman wafat, estafet kepemimpinan Ponpes Tanjung Salam dilanjutkan oleh putra beliau yang bernama Ust. Dindin Awaludin. Yang pada awalnya beliau merasa belum pantas memegang jabatan setinggi itu, namun atas desakan dari masyarakat dan beberapa kiyai setempat, beliau pun menyanggupinya.

Ustadz Dindin Awaludin lulusan dari Universitas Islam Negeri, maka alur kebijakan dan pengembangan Pondok pun lebih kearah modernisasi, namun tentunya tidak mengubah ataupun meninggalkan tradisi lama. Sebab pada saat dahulu ayahandanya berpesan untuk tidak mencampuradukkan Ponpes kedalam pemerintahan.

Dalam memimpin Ponpes Tanjung Salam, Ust. Dindin Awaludin memiliki 
landasan yaitu "Menjaga tradisi lama dan memasukkan tradisi baru yang lebih baik". Maka dari itu beliau berusaha untuk tidak meninggalkan tradisi-tradisi lama Kiyai terdahulu dan membuka wawasan baru bagi para santri agar berpengetahuan luas, tidak hanya sebatas ilmu-ilmu agama tetapi juga ilmu-ilmu kehidupan.

Pada tahun 2008, Ust. Dindin Awaludin mendirikan Yayasan dengan maksud untuk mengembangkan Ponpes dan membantu masyarakat sekitar yang memang rata-rata ekonominya menengah ke bawah. Beliau bekerjasama dengan masyarakat sekitar untuk mengembangkan SDM di bidang wirausaha dan jasa. Dan Alhamdulillah, walhasil perekonomian masyarakat sekitar mulai menggeliat.

Pondok Pesantren Tanjung Salam tentunya hampir identik dengan lembaga pendidikan sekolah yang lebih formal, akan tetapi ada hal yang sangat signifikan yang membedakan yakni Pondok Pesantren Tanjung Salam lebih dominan bergerak dalam hal pendidikan agama Islam yakni pembinaan Al-qur'an dan pendalaman kitab-kitab kuning yang penyelenggaraannya alhamdulillah secara intensif dapat diikuti oleh para santri atau siswa.

Eksistensi Pondok Pesantren Tanjung Salam di lingkungan kampung Ciseupan alhamdulillah telah mampu berperan aktif, seperti dalam upaya pemberantasan buta huruf Al-Qur'an serta pengkajian dan pendalaman kitab-kitab kuning dikalangan anak-anak, kaum remaja di kampung Ciseupan dan para santri yang datang dari luar daerah, bahkan para orang tua pun telah mampu dilaksanakan diantaranya dengan mengadakan pengajian rutinan, karena mengingat masyarakat kampung ciseupan merupakan sasaran utama dan pertama yang mendukung akan kemajuan Pondok Pesantren Tanjung Salam pada khususnya juga untuk kemajuan Islam pada umumnya. Sehingga telah mampu mencetak para santri yang memiliki potensi yang bisa berperan aktif dalam pengembangan pendidikan Al-Qur'an, diantaranya dalam hal pengutusan para peserta MTQ dari tingkat daerah hingga tingkat Nasional, dan alhamdulillah telah melahirkan para santri yang telah berprestasi seperti Nadzir Minhatul Maula (Juara MSQ tingkat Kabupaten Bandung tahun 2000) Salman Amrillah (Juara I MMQ Anak-anak Putera tingkat Kabupaten Bandung tahun 2001, Juara I Tahfidz AlQuran 1 Juz tingkat Nasional pada kegiatan Festival Anak Soleh di Jakarta tahun 2005) Intan Yuli Susanti (Juara MMQ Anak-anak Puteri tingkat Kabupaten Bandung dan Propinsi Jawa Barat tahun 2002).

Selain itu, banyak lagi prestasi yang dihasilkan oleh para santri yang lainnya, seperti mendapat kepercayaan dari masyarakat dengan cara mengisi pengajian di luar lingkungan kampung Ciseupan yaitu mengisi Ceramah Umum atau mengisi Tabligh Akbar pada acara Peringatan Hari Besar Islam, namun kelegalitasan pondok pesantren ini sampai sekarang belum begitu dikenal di kalangan masyarakat luas, pemerintahan, instansi bahkan para birokrat, sehingga hal inilah salah satu upaya untuk lebih mengenalkan dan mempublikasikan secara lebih jauh 
N. Khirzani., D. I. Effendi., A. Mujib.

guna melegalitaskan akan adanya salah satu sarana pendidikan agama yang kiranya perlu diselenggarakan di lingkungan bangsa Indonesia pada umumnya melalui lembaga yang berbadan hukum yaitu Yayasan Al-Baehaqi.

Adapun penyelenggaraan yang dilaksanakan oleh Yayasan Sosial dan Pendidikan Islam Al-Baehaqi saat ini berupa Sosial dan Pendidikan Islam meliputi: (1) Pondok Pesantren Tanjung Salam; (2) Diniyah Takmiliyah (DT) Tanjung Salam; (3) Pendidikan Anak Usia Dini (PAUD) Tanjung Salam; dan (4) Raudhatul Athfal (RA) Tanjung Salam.

Tabel 1

Data Santri Ponspes Tanjung Salam

\begin{tabular}{lllll}
\hline No & Santri & Putra & Putri & Jumlah \\
\hline 1. & Mukim & 78 & 32 & 110 \\
2. & Non Mukim & 25 & 20 & 45 \\
3. & PAUD & 50 & 45 & 95 \\
4. & TPA & 36 & 35 & 71 \\
5. & Jumlah & 189 & 132 & 321 \\
\hline
\end{tabular}

Sumber data didapat dari wawancara yang dilakukan kepada Ust. Dindin dan data yang tersimpan di dokumen administrasi yayasan pada 24 Desember 2017.

Tabel 2

Jadwal Mengaji Mingguan Santri

\begin{tabular}{lll}
\hline No. & Minggu & Pengajar \\
\hline 1. & Ke 1 & KH. Rizal Sanusi \\
2. & Ke 2 & Dindin Awaludin S.Pd.I \\
3. & Ke 3 & Ust. Nandang Wiharya \\
4. & Ke 4 & Ust. Abu Mansur \\
\hline
\end{tabular}

Sumber data didapat dari wawancara yang dilakukan kepada Ust. Dindin dan data yang tersimpan di dokumen administrasi yayasan pada 24 Desember 2017. 
Tabel 3

Jadwal Kegiatan Harian Santri

\begin{tabular}{ll}
\hline Jam & kegiatan \\
\hline $04.00-05.00$ & Bangun tidur, Mandi, Lalu Sholat. \\
$05.00-06.30$ & Mengaji kitab kuning yang sudah terjadwal di Majelis. \\
$06.30-07.00$ & Bersih-bersih di rumah Kiyai dan Ibu Pengasuh. \\
$07.00-12.00$ & Sekolah bagi anak santri yang bersekolah. \\
$08.00-09.00$ & $\begin{array}{l}\text { Istirahat sejenak, diisi dengan kegiatan pribadi bagi santri yang } \\
\text { mukim. }\end{array}$ \\
$09.00-11.00$ & Pengajian yang sudah terjadwal di Mesjid. \\
$11.00-$ selesai & Makan siang, muthola'ah dan istirahat. \\
$11.45-$ selesai & Siap-siap untuk Sholat Dzuhur. \\
$12.00-17.00$ & Sekolah bagi para santri yang bersekolah siang. \\
$15.00-$ selesai & Sholat Ashar. \\
$16.00-17.00$ & $\begin{array}{l}\text { Mengaji kitab yang sudah terjadwal di Mesjid. } \\
\text { Sholat Maghrib. }\end{array}$ \\
$17.40-$ selesai & $\begin{array}{l}\text { Mengaji sesuai dengan jadwal di Majelis. } \\
\text { Shalat Isya, Makan dan Tidur. }\end{array}$ \\
\hline
\end{tabular}

Sumber : wawancara Ust. Dindin serta dokumen Ponpes pada 24 Desember 2017

Keterangan :

Bagi para santri yang tidak bersekolah, kegiatan sehari-harinya diisi dengan berbagai pelatihan usaha keterampilan diantaranya : membuat Peci (kopiah) dengan berbagai warna dan corak khas Tanjung Salam, membuat telor asin, hingga menjajakan barang dagangan.

Para santri pun diajarkan ilmu-ilmu atau keterampilan yang sangat familiar dan dibutuhkan dalam kehidupan masyarakat nantinya, diantaranya : diajarkan teknik berpidato atau ceramah yang baik, cara menjadi Khotib dan Imam yang baik, diajarkan cara menjadi Nai'b (orang yang suka menikahkan pengantin), diajarkan cara mengkhitan yang benar dan lain sebagainya. 
N. Khirzani., D. I. Effendi., A. Mujib.

\section{Proses Pelaksanaan Bimbingan Agama di Ponpes Tanjung Salam}

Dalam penelitian proses bimbingan bimbingan agama yang dilaksanakan di Pondok Pesantren Tanjung Salam, peneliti mewancarai pimpinan Pondok Pesantren Tanjung Salam yaitu Ust Dindin sebagai pembina sekaligus pimpinan pondok (24 Desember 2017) beliau mengatakan bahwa ada beberapa point yang terkait dalam proses bimbingan agama dalam meningkatkan ketauhidan remaja di pondok pesantren Tanjung Salam, diantaranya yaitu;

Pembimbing (Ustadz)

Mufidah (2015: 189) pembimbing atau mursyid didefinisikan sebagai :

"seseorang yang shalih yang dapat menyembuhkan penyakit ruhani manusia."

sementara itu, pengertian orang shalih sendiri Mufidah (2015: 189) jelaskan sebagai :

"seorang yang mampu mengintegrasikan dirinya dan mampu mengaktualisasikan potensinya semaksimal mungkin dalam berbagai dimensi kehidupan."

Adapun pembimbing (mursyid) atau ustadz yang memberikan meteri bimbingan adalah ustadz-ustadz yang telah ditunjuk dan dipercaya oleh pengurus dan juga pimpinan pesantren yaitu diantaranya: (1) Ust. Dindin Awaluddin, Selain sebagai pengajar Ust. Dindin juga merupakan pimpinan Pondok Pesantren dan Yayasan Al Baehaqi Tanjung Salam ia mengajarkan atau membimbing santri dengan sumber kitab tijannuddarary fi syarbil bajuri. Ia merupakan lulusan UIN Sunan Gunung Djati Bandung yang lulus pada tahun 2004. (2) Ust. Nanang Wiharna, Ia adalah salah satu pengajar yang mengajar ketauhidan dengan sumber kitab syu'bul iman. Selain itu Ust. Nanang juga merupakan salah seorang penasihat di yayasan dan pondok pesantren tanjung salam. Ia merupakan salah seorang alumni dari pesantren Tanjung Salam selain itu juga pernah menimba ilmu di salah satu pesantren di daerah Sumur Bandung. (3) Ust. Sofyan Sauri, Ia adalah pengajar salah satu kitab ketauhidan yang lain yaitu kitab 'durottun nashibin. Ia merupakan alumni dari salah satu pesantren di daerah Tasik yaitu Pondok Pesantren Cipasung.

Terbimbing (para santri)

Rusmalita (2015: 131-132) menjelaskan bahwa dalam melakukan suatu dakwah dalam hal ini bimbingan alangkah lebih baiknya bila seorang pembimbing itu sebelum memberikan materi, juga diharapkan mengetahui keadaan mad'unya, baik secara psikologis, sosial ekonomi dan sebagainya. Masih dalam sumber yang sama dijelaskan pula bahwa statementnya tersebut didukung dengan pernyataan seorang cendekia muslim yaitu Mustafa Al Maraghi dalam Alwisral yaitu seorang 
Bimbingan Agama dalam Meningkatkan Pemahaman Ketauhidan Remaja

Da'i (pembimbing) hendaklah mengetahui dan pandai membaca situasi umat yang diberi dakwah, baik dalam urusan bakat, watak dan akhlak mereka atau ringkasnya mengetahui kehidupan mereka.

Dalam praktiknya di dalam Bimbingan selain dari adanya pembimbing (Ustadz/ Ustadzah) tentu saja ada unsur lainnya yang tidak kalah penting yaitu terbimbing yaitu para santri yang mengikuti kegiatan di Pondok Pesantren Tanjung Salam dengan semua programnya.

Latar belakang santri yang mengikuti kegiatan di pondok pesantren Tanjung Salam adalah santri yang berusia sekitar 12 sampai dengan 18 tahun atau bersekolah diantara jenjang pendidikan SMP/ Mts dan SMA/ SMK/ MA sederajat. Semua santri diwajibkan tinggal di pondok asrama selama mengikuti program mengaji (Bimbingan Agama) dan tentu saja diwajibkan pula untuk mengikuti peraturan dan tata tertib yang telah ditentukan oleh pihak pondok pesantren. Para santri yang dimbing oleh pembimbing (Ustadz/ Ustadzah) dalam proses Bimbingan Agama ditargetkan agar dapat memahami pembelajarannya minimal dasar-dasarnya (hasil wawancara dengan Ustadz Dindin dan beberapa pembimbing lainnya, 24 Desember 2017).

Materi

Jazuli (2016: 9) menjelaskan bahwa materi pendidikan karakter terbagi ke dalam lima fase yaitu : fase 3-6 tahun, fase 7-8 tahun, fase 9-10 tahun, fase 11-12 tahun dan fase 13 tahun ke atas. Pda tiap fase memiliki penerapan pendidikan karakter yang berbeda-beda tergantung jenjang fasenya. Sementara itu, karakter atau akhlak (materi) yang diberikan rata-rata berupa tawakkal, menghormati, takwa, memaafkan, berkata baik, berkata benar, memelihara lingkungan, dan menghargai privasi orang lain, amanah, pemberani, sabar, malu, lemah lembut, kasih sayang, tawadhu/ rendah hati, amanah, pemberani, sabar, riang gembira, berkata jujur, lemah lembut, memuliakan tamu dan menghormati orang lain.

Selanjutnya terkait dengan proses bimbingan agama ini, unsur yang ketiga adalah materi bimbingan yang disampaikan oleh pembibing (Ustadz/ Ustadzah). Adapun ada beberapa materi yang disampaikan kepada para santri dalam proses bimbingan agama melalui beberapa metode khas pesantren. 1) Materi Kajian Kitab Kuning, Materi yang diberikan pertama kali adalah materi yang berpanduan atau berpedoman pada kajian kitab kuning. Adapaun kitab yang dikaji secara intensif diantaranya adalah Tîjān al-Darāry syarah Matan al-Bājûry karya Syeikh Muhammad Nawawi Al-Jawi yang merupakan salah satu dari tiga ulama Indonesia yang mengajar di Masjid Al-Haram di Makkah Al-Mukaromah pada akhir abad ke19 dan awal abad ke-20. Dan dua lainnya adalah muridnya, yaitu Ahmad Khatib Minangkabau dan Kiai Mahfudz Termas.

Kitab ini ditulis pada tahun $1301 \mathrm{H}$ dan diterbitkan oleh Pustaka Al- 
Alawiyah Semarang dan kitab ini merupakan syarah (penjelasan) dari risalah alBajuri fi at-Tauhidi yang ditulis oleh Syaikh Bajuri sehingga kitab ini dinamai dengan "Tîjān Al-Darāry Fi Syarhi Ar Risalah Al- Bājûry" dengan bahasa arab dan telah diterjemahkan oleh Ustadz Achmad Sunarto kedalam bahasa Indonesia.

Kitab ini berisi tentang ilmu ketauhidan yang menuntun kita untuk lebih mengenal Allah SWT lewat sifat-sifatNya. Kitab ini juga menjelaskan tentaang sifat-sifat wajib dan jaiz bagi Allah SWT dan rasul-Nya serta nasab Rasullullah SAW. Ada ungkapan "tak kenal maka tak sayang", kiranya itulah yang merupakan pokok dari adanya sifat tauhid adalah emngenali pencipta lalu secara berangsurangsur dapat mengenali, memahami, dan akhirnya menyayangi serta dapat mengaplikasikannya ke dalam kehidupan sehari-hari.

Secara keseluruhan al-Qur'an telah menjelaskan banyak mengenai Allah SWT, baik dari segi zat, sifat, asma dan af'al (perbuatan) Allah SWT serta sifatsifat Rasulullah SAW. Sudah kita ketahui bahwa al-Qur"an adalah kitab Allah SWT yang paling kuat dan valid yang terdapat di muka bumi ini, dia kuat dengan bentuk yang mutawatir (istilah ahli hadis) yang manusia tidak akan mungkin meragukan lagi keabsahan atau kevalidan teks-teksnya serta kevalidanya dari segi ketauhidan, maka hal-hal yang al-Qur"an jelaskan mengenai zat, sifat, asma dan of"al Allah SWT serta sifat-sifat Rasulullah SAW dalam ilmu ketauhidan merupakan sumber yang paling valid secara mutlak.

Menurut pengamatan penulis al-Qur"an telah memaparkan mengenai ketauhidan Allah SWT secara terperinci, baik dari segi zat, sifat, asma, serta af' alNya. Meskipun demikian, alangkah lebih baiknya kalau kita tetap mau mengkaji sumber-sumber yang lain, supaya kita dapat menambah perbendaharaan pengetahuan tentang ilmu ketauhidan, sehingga kita bisa benar-benar mengenal Allah SWT dan Rasul-Nya secara detail.

Hadits Rasulullah SAW yang shabîh, yang dimuat oleh kitab-kitab para ulama hadist yang di kenal dengan sifat keterpercayaan mereka dalam dunia Islam, seperti kitab sunnah yang enam, yaitu: kitab Shabîh Bukhäri, kitab Shahîh Muslim, kitab Abu Daud, kitab Tirmidř̂, kitab an-Nasä"i, dan kitab Ibnu Majah, serta kitab-kitab yang lainnya seperti: kitab al-Mwnatha" oleh Imam Malik dan kitab Musnad Imam Hanbal.

Kitab-kitab ini, khususnya kitab Shabîh Bukbäri dan Muslim keduanya menempati posisi derajat paling shabîh (kuat), adapun kitab-kitab yang lain di dalamnya memuat hadits-hadits selain hadits-hadits shabîh, seperti hadits hasan dan juga dhoif (lemah).

Dari kitab-kitab ini yang memuat jumlah yang besar tentang tauhid, yaitu meliputi sifat-sifat, zat, asma dan af"al Allah SWT. Dengan hal ini, semoga akan 
menambah keyakinan yang sempurna dalam diri kita terhadap akidah ketuhanan dalam Islam, karena terkadang kita masih berada atas metode yang salah dalam memahami keesaan dan penyucian zat Allah SW'T, lalu menarik kesalahan ini pada pendapat dengan sempurna (absolut), seperti ketiadaan secara absolut pula dalam keesaan dalam praktik dan keesaan dalam kehendak. Oleh karena itu kitab-kitab ini disusun sebagai pedoman kedua setelah al-Qur"an untuk menyempurnakan aqidah ketuhanan umat manusia di seluruh dunia ini. Diantara faktor yang menambah rasa kepercayaan kita kepada Allah SWT ialah halihwal tentang-Nya diriwayatkan dengan sanad (istilah ilmu hadits) yang bersambung sampai kepada Sahabat-sahabat Rasulullah SAW.

Kitab Tîjān al-Darāry ini dibagi menjadi lima pembahasan, yaitu pembahasan pertama tentang kewajiban seorang mukallaf untuk mengenal sifatsifat wajib dan mustahil bagi Allah SWT, pembahasan kedua tentang kewajiban seorang mukallaf untuk mengetahui sifat jaiz bagi Allah SWT, pembahasan ketiga tentang diharuskan bagi setiap mukallaf untuk mengetahui semua sifat wajib dan mustahil bagi para Rasul Allah SWT, pembahasan keempat tentang setiap mukallaf wajib mengetahui tentang sifat jaiz bagi Rasulullah SAW. Pembahasan kelima tentang setiap mukallaf wajib mengetahui nasab Rasul dan permasalahan yang lainnya.

Kewajiban Seorang Mukallaf untuk Mengenal Sifat-Sifat Wajib dan Mustahil bagi Allah SWT dari Masan AF (2009: 16-20) meliputi: (a) Sifat Wujud bagi Allah SWT, Sifat Wujud ialah kepastiaan adanya Allah. Maksudnya, Allah pasti ada. Bukti bahwa Allah itu ada adalah wujud makhluk. (b) Sifat Qidam bagi Allah SWT, Sifat Qidam ialah ketiadaan permulaan bagi keberadaan atau wujud Allah, sebab Allah adalah sumber semua makhluk, (c) Sifat Baqa' bagi Allah SWT, Sifat Baqo ialah tiada akhir bagi keberadaan atau wujud Allah, (d) Allah SWT tidak Menyerupai Makhluknya, Sifat Mukholafatul lil hawaditsi ialah Allah Ta'ala itu tidak dapat disamai oleh makhluk apa pun dan tidak menyamai makhluk. (e) Allah SWT Berdiri Sendiri, Sifat Qiyamuhu binafsihi ialah Allah itu tidak butuh kepada apa pun dan tidak butuh kepada siapa pun. Buya Yahya Menjawab Allah Ada Di Mana - Penjelasan Hadits Riwayat Muslim tentang jariyah yang ditanya oleh Rasulullah "Allah Ada di Mana? lalu ia menjawab di Langit. Kemudian Ayat Allah ber-Istiwa' di Langit dll. (f) Allah SW'T Maha Esa, Sifat Wahdaniyyat ialah Allah itu Tunggal, Mandiri, tiada sekutu bagi-Nya, baik dalam perbuatan, sifat maupun Zat-Nya. (g) Allah SWT Maha Kuasa, Sifat Qudrot ialah kemampuan Allah menciptakan dan meniadakan apa saja yang Dia kehendaki berdasar keinginanNya. Apabila Allah tidak mempunyai kemampuan, tentu Dia tidak dapat mencipta makhluk sekecil apa pun. (h) Allah SWT Maha Berkehendak, Sifat Irodat ialah kehendak menakdirkan sesuatu sebelum menciptakannya. Allah memiliki kebebasan menciptakan apa saja sesuai kehendak-Nya dan pilihan-Nya. Karena 
itu, adakalanya Dia menciptakan sesuatu berbentuk panjang, tinggi atau pendek, ada yang bagus dan ada yang jelek, adakalanya pandai dan adakalanya bodoh. (i) Allah SWT Maha Ilmu, Sifat 'Ilmu ialah Allah mengetahui terhadap segala sesuatu yang telah berlalu, yang sedang terjadi dan yang akan terjadi. (j) Allah SWT Maha Hidup, Sifat Hayat ialah Allah itu Maha Hidup dan Kekal serta tidak bakal sirna. Allah swt. (k) Allah SWT Maha Mendengar, Sifat Sama’ ialah didengarnya segala sesuatu oleh Allah. Allah mendengar segala sesuatu yang tidak dapat didengar oleh selain-Nya. (1) Allah SWT Maha Melihat, Sifat Bashor ialah terlihatnya segala sesuatu oleh Allah. Tidak ada sesuatu pun yang lepas dari pandangan Allah. Allah swt. (m) Allah SWT Maha Berbicara atau Kalam, Sifat Kalam ialah bahwa Allah itu Maha Bicara. Allah swt. (n) Allah SW'T Maha Kuasa Wajib aqli Allah mempunyai sifat Kaunuhu Qodiron, artinya terbukti Allah yang Maha Kuasa dan Mustahil Allah tidak Kuasa. Adapun dalil - dalilnya cukup dengan sifat Qudrot. (o) Allah SW'T Maha Menghendaki, Wajib aqli Allah mempunyai sifat Kaunuhu Muridan, artinya terbukti Allah yang Maha berkehendak dan mustahil Allah tidak mempunyai kehendak. Adapun dalil - dalilnya cukup dengan sifat Irodat. (p) Allah SWT Maha Mengetahui, Wajib aqli Allah mempunyai sifat Kaunuhu 'Aliman, artinya terbukti Allah yang Maha Mengetahui dan mustahil Allah yang bodoh. Adapun dalil - dalilnya cukup dengan sifat 'Ilmu. (q) Allah SWT Maha Hidup atau Hayyan, Wajib aqli Allah mempunyai sifat Kaunuhu Hayyan, artinya terbukti Allah yang Hidup dan mustahil Allah mati. Adapun dalil - dalilnya cukup dengan sifat Hayat. (r) Allah SWT Maha Mendengar. wajib aqli Allah mempunyai sifat Kaunuhu Sami'an, artinya terbukti Allah yang Maha Mendengar dan mustahil Allah yang tuli. Adapun dalil - dalilnya cukup dengan sifat Sama'. (s) Allah SW'T Maha Melihat, Wajib aqli Allah mempunyai sifat Kaunuhu Bashiron, artinya terbukti Allah yang Maha Melihat dan mustahil Allah yang buta. Adapun dalil dalilnya cukup dengan sifat Bashor. (t) Allah SW'T Maha Berbicara atau Mutakaliman, Wajib aqli Allah mempunyai sifat Kaunuhu Mutakalliman, artinya terbukti Allah yang Berfirman, dan mustahil Allah yang bisu. Adapun dalil dalilnya cukup dengan sifat Kalam.

Setelah mengetahui sifat-sifat Allah dan juga artinya maka seorang Mukallaf Wajib Mengetahui Sifat Jaiz bagi Allah SW'T. lalu setelah itu diharuskan bagi Setiap Mukallaf Mengetahui Semua Sifat Wajib dan Mustahil bagi Rasul meliputi: (1) Seorang Rasul Wajib Mempunyai Sifat Shiddiq (Jujur); (2) Seorang Rasul Wajib Mempunyai Sifat Amanah (Dapat dipercaya); (3) Seorang Rasul Wajib Mempunyai Sifat Tabligh (Menyampaikan); dan (4) Seorang Rasul Wajib Mempunyai Sifat Fathanah (Cerdas)

Setelah itu maka berlanjut dengan setiap Mukallaf Wajib Mengetahui Sifat Jaiz bagi Rasul. Pertama, Setiap Mukallaf Wajib Mengetahui Nasab Rasul dan Permasalahan lainnya, meliputi Garis Nasab Nabi Muhammad SAW, Telaga Nabi 
SAW di Surga, Syafaat Rasulullah SAW, Para Rasul yang disebut dalam al-Qur'an secara Terperinci, Kurun Waktu Rasulullah SAW adalah yang Terbaik, dan Keutamaan Ahlul Bait. Meskipun seluruh kitab karya Syaikh Muhammad Nawawi al-Jawi ditulis dengan bahasa arab, namun tetap mudah dipahami oleh orang-orang yang mempelajarinya, misalnya dikalangan para santri, siswa dan mahasiswa, karena pembahasanya disesuaikan dengan kebutuhan masyarakat pelajar.

\section{Proses Pemberian Motivasi}

Perilaku yang penting bagi manusia adalah belajar dan bekerja. Belajar menimbulkan perubahan mental pada siswa, sementara bekerja menghasilkan sesuatu yang bermanfaat bagi diri mereka. motivasi dalam belajar dan bekerja (beribadah) merupakan penggerak i'tikad baik pada siswa.

Menurut Mujiyono dan Dimyati (2006: 85) motivasi belajar sangat penting bagi siswa, pentingnya motivasi belajar bagi siswa adalah sebagai berikut : (a) menyadarkan kedudukan pada awal belajar proses dan hasil akhir; (b) menginformasikan tentang kekuatan usaha belajar, yang dibandingkan dengan teman sebaya; (c) mengarahkan kegiatan belajar; (d) membesarkan semangat belajar; dan (e) menyadarkan bahwa ada perjalanan belajar dan kemudian melakukan pekerjaan yang berkesinambungan. Maka dari itu penting sekali pemberian motivasi kepada siswa atau santri ini dilakukan.

Tujuan dari diadakannya motivasi adalah agar proses bimbingan yang dilakukan dapat berjalan lebih baik dan lancar. Karena mempelajari tauhid tanpa dorongan motivasi yang kuat baik dari internal ataupun dari eksternal diri santri itu sendiri, maka santri akan mudah goyah atau tidak dapat menyerap materi bimbingan dengan baik dan efektif.

Marlina (2012: 253) menurutnya motivasi bagi remaja tidak bisa dilakukan dengan cara paksa melainkan dengan cara memberikan perhatian ekstra. Rahim (2006: 85) mendefinisikan motivasi sebagai suatu tenaga atau faktor yang terdapat dalam diri manusia yang menimbulkan, mengarahkan dan mengorganisasikan tingkah laku seseorang. Adapun faktor yang mempengaruhi motivasi seseorang antara lain yaitu faktor eksternal diantaranya : dukungan sosial, lingkungan dan orang tua. Sementara faktor internal adalah faktor dalam diri individu yaitu kepercayaan diri yang timbul karena tekad dan perasaan untuk mampu melaksanakan segala yang dibutuhkan dalam hidup. Adapun motivasi yang diberikan diantaranya berupa :

Pertama, Pembimbing terus mengajarkan metode yang termudah dalam memahami kajian yang dilakukan baik saat melakukan kajian bersama maupun kajian yang dilakukan secara privat. Kedua, Pembimbing mengadakan sharing atau 
N. Khirzani., D. I. Effendi., A. Mujib.

diskusi berkaitan dengan materi yang diberikan. Ketiga, Pembimbing memberikan tausyiah tentang pentingnya tauhid sebagai pokok atau dasar dari seluruh tindakan yag dilakukan oleh manusia.

Keempat, Pembimbing menyampaikan manfaat-manfaat dari mempelajari tauhid dan bagaimana cara mengaplikasikannya dalam kehidupan sehari-hari. Kelima, Berqisah tentang orang-orang yang berkehidupan sesuai dengan ajaran tauhid lalu mengmbil hikmah dari setiap kejadiannya. Keenam, Memberikan reward pada santri yang telah dapat melaksanakan materi yang telah diberikan dengan baik. Baik itu berupa sanjungan ataupun berupa barang. Cara ini dilakukan secara bebrkelanjutan agar santri terus dapat termotivasi dan lebih semangat dalam memeplajari dan memahami tentang pembelajaran atau bimbingan keagamaan yang diberikan (wawancara kepada Ust. Dindin, Pimpinan Pondok Pesantren Tanjung Salam 24 Desember 2017).

\section{Media dan Metode Bimbingan Agama di Ponpes Tanjung Salam}

Selanjutnya dalam proses bimbingan agama dalam upaya meningkatkan pemahaman ketauhidan pada remaja (santri) pondok pesantren Tanjung Salam adalah media, media merupakan saluran atau alat penyampai pesan bimbingan yang diberikan dan digunakan dengan tujuan agar proses bimbingan yang dilakukan dapat terjalin dengan lebih baik lagi. Adapun media yang digunakan santri dalam proses memahami materi ketauhidan itu sendiri adalah berupa alatalat bantu yang dapat memperlancar proses bimbingan keagamaan supaya lebih mudah dan praktis diantaranya adalah buku,-buku tauhid, kitab kuning dan lain sebagainya.

Dari wawancara yang telah dilakukan kepada pimpinan Pondok Pesantren Tanjung Salam dapat disimpulkan bahwa ada dua metode yang diberikan oleh pembimbing di Pondok Pesantren Tanjung salam ini, yaitu: Pertama, Bandongan atau Bandungan, Istilah bandungan berasal dari bahasa Sunda yaitu ngabandungan yang berarti memperhatikan secara seksama atau menyimak. Dengan metode ini, para akan belajar menyimak. Dengan metode ini, para santri akan dengan seksama menyimak secara kolektif atau bersama-sama. Namun, dalam bahasa jawa bandongan juga disebut berasal dari kata bandong yang artinya pergi berbondongbondong, hal tidak bertolak belakang dengan pengertian sebelumnya yaitu bersama-sama. Kedua, Sorogan, Secara bahasa kata sorogan berasal dari bahasa jawa yaitu sorog, yang artinya menyodorkan, yang berarti metode ini dilakukan oleh santri dengan keinginannya sendiri, materi yang dibahaspun tergantung yang ingin dipelajari oleh santri itu sendiri. Sorogan merupakan metode pembelajaran yang diterapkan di pesantren hingga kini, terutama di epsantren salaf. Usia dari metode ini diperkirakan lebih tua dari pesantren itu sendiri. Karena metode ini telah dikenal semenjak pendidikan Islam dilakukan di langgar-langgar. Saat anak-anak 
belajar al-qur'an kepada seorang ustadz atau kiai di kampung-kampung.

Terbimbing dalam hal ini adalah para santri pondok pesantren Tanjung Salam jika dilihat dari latar belakang santri yang mengikuti kegiatan bimbingan keagamaan di pondok pesantren Tanjung Salam yaitu terdiri dari santri yang berusia sekitar 12 sampai dengan 18 tahun atau bersekolah diantara jenjang pendidikan SMP/ Mts sampai dengan SMA/ SMK/ MA sederajat. Semua santri diwajibkan tinggal di pondok asrama selama mengikuti program mengaji (Bimbingan Agama) dan tentu saja diwajibkan pula untuk mengikuti peraturan dan tata tertib yang telah ditentukan oleh pihak pondok pesantren.

Pada penelitian ini peneliti lebih menekankan pada proses bimbingan yang dilakukan di pondok pesantren Tanjung Salam, selain itu juga peneliti mempertimbangkan tingkat pemahaman tentang tauhid yang terdapat pada santri pondok pesantren Tanjung Salam juga bagaimanakah pengaruh dari adanya proses bimbingan agama yang dilakukakan oleh para pembimbing.

Pada bagian ini akan dijelaskan secara jelas bagaimana tingkat pemahaman tentang ketauhidan yang dimiliki oleh para santri di pondok pesantren Tanjung Salam secara jelas pemahaman dapat diartikan sebagai suatu keadaan dimana seseorang dapat mengerti secara benar tentang sesuatu. Jadi jika disangkutpautkan ked alam ketauhidan maka pemahaman ketauhidan berarti keadaan dimana seseorang mengerti betul tauhid itu secara benar.

Seperti yang telah dijelaskan pada bab terdahulu bahwa konsep tauhid dalam agama Islam pada intinya adalah beriman dan meng-Esakan Allah sementara itu, iman dan segala bentuk penghambaan lain seperti melaksanakan shalat, zakat, puasa, iman kepada malaikat, kitab, nabi \& rasul, hari kiamat dan juga takdir adalah menifestasi dari keimanan kepad Allah tersebut.

Sementara itu, dijelaskan pula pada bab sebelumnya bahwa konsep pemahaman tauhid di kalangan remaja sebagai sebuah fase yang merupakan titik tolak dari masa anak-anak menuju masa dewasa atau baligh dan menjadi mukallaf dijelaskan dalam kitab Tijannuddarori yang dipelajari di pondok pesantren Tanjung Salam yang di dalamnya terdapat lima esensi utama, yaitu diantaranya :

Pertama, tentang kewajiban seorang mukallaf untuk mengenal sifat- sifat wajib dan mustahil bagi Allah SWT; Kedua, tentang kewajiban seorang mukallaf untuk mengetahui sifat jaiz bagi Allah SWT; Ketiga, tentang diharuskan bagi setiap mukallaf untuk mengetahui semua sifat wajib dan mustahil bagi para Rasul Allah SWT; Keempat, tentang setiap mukallaf wajib mengetahui tentang sifat jaiz bagi Rasulullah SAW; dan Kelima,tentang setiap mukallaf wajib mengetahui nasab Rasul dan permasalahan yang lainnya.

Dari kitab tersebut maka diambillah inti dari tauhid itu sendiri, meskipun 
merupakan dasar dari ketauhidan. Bukankah dasar adalah penentu kuat tidaknya sebuah bangunan.sementara itu, dalam pengaplikasiannya dalam kehidupan konsep ketauhidan dalam kitab tijannuddarori itu sendiri adalah dengan memahami dengan betul esensi dari tiap kewajiban mengetahui berbagai konsep ketauhidan seperti sifat wajib, jaiz Allah dan rasulnya serta dapat mengambil pelajaran atau contoh dari sifat-sifat tersebut. (Wawancara dengan Ust. Dindin pada 24 Desember 2017).

Setelah mejelaskan proses bimbingan keagamaan mulai dari pembimbing, terbimbing, materi, dan media dalam bimbingan agama, untuk selanjutnya yaitu proses pemberian bimbingan yang diberikan kepada santri oleh pembimbingnya. Dimana dalam proses bimbingan ini ada beberapa tahapan yang perlu diperhatikan oleh para santri yang diterapkan di Pondok Pesantren Tanjung Salam. Diantaranya yaitu;

Pertama, Meluruskan niat, niat adalah awal dari semua amal. Sesungguhnya amal itu tergantung niatnya. Bila niatnya baik dan ikhlas, maka baiklah amalnya. Namun bila niat keliru maka sia-sia amalnya. Dalam hal niat ini, semua santri dipondok Pesantren Tanjung Salam di haruskan berniat terlebih dahulu dalam mempelajari dan memahami tauhid itu sendiri serta meluruskan niatnya supaya berbuah pahala. Salah satu niat yang di sarankan oleh pimpinan pondok pada santri dalam proses memahami tauhid diantaranya ialah; Berniat karena Alloh untuk lebih mencintainya; Berniat untuk memperbanyak dan berlaku sesuai dengan ketentuannya; Berniat melaksanakan Qiyamul lail (solat tahajud) dengan mengulas kembali materi yang diberikan; Berniat memperoleh kemuliaan sebagai seorang hamba Allah ayng bertaqwa; Berniat agar kedua orang tua kelak pada hari kiamat akan dikenakan mahkota kemuliaan; Berniat membentengi diri dari siksa dan murka Allah akhirat; Berniat mengajarkannya kepada orang lain; Berniat menjadi suri teladan yang baik bagi kaum muslim dan non muslim. (hasil wawancara dengan Ust Dindin pada 24 Desember 2017).

Pemberian Materi Bimbingan Keagamaan melalui kajian yang dilakukan oleh ustadz dengan cara menerjemahkan dan lalu menjelaskannya kepada santri kitab kuning tersebut bersamaan dengan itu santri memperhatikan sambil memahami apa isi atau hasil kajian kitab kuning tersebut untuk selanjutnya mereka terapkan dalam kehidupan sehari-hari.

\section{PENUTUP}

Pertama, Pada proses pelaksanaan pembelajaran dan juga bimbingan agama ini ada beberapa hal yang dilakukan diantaranya adalah meluruskan niat, dan lalu ustadz atau pembimbing memberikan bimbingan keagamaan melalui kajian kitab dalam hal ini adalah kitab tijan ad-darory fi syarbil badjury kepada santri yang sedang 
menginjak masa remaja, setelah itu para santri diberikan penjelasan lebih lanjut tentang isi kajian tersebut diantaranya adalah mengenai lima point penting yang terdapat di dalam kitab tijan ad-darory fi syarbil badjury ini yaitu (1) pembahasan tentang kewajiban seorang mukallaf untuk mengenal sifat- sifat wajib dan mustahil bagi Allah SWT; (2) Pembahasan kedua tentang kewajiban seorang mukallaf untuk mengetahui sifat jaiz bagi Allah SWT; (3) Pembahasan ketiga tentang diharuskan bagi setiap mukallaf untuk mengetahui semua sifat wajib dan mustahil bagi para Rasul Allah SWT; (4) Pembahasan keempat tentang setiap mukallaf wajib mengetahui tentang sifat jaiz bagi Rasulullah SAW; dan (5) Pembahasan terakhir adalah tentang setiap mukallaf wajib mengetahui nasab Rasul dan permasalahan yang lainnya. Tahapan ini tentu saja dilakukan dengan mempertimbangkan kesesuaian dengan kemampuan santri yang masih berusia remaja. Selain itu, bimbingan keagamaan yang dilakukan yang dilakukan meliputi 5 aspek penting yaitu : Pembimbing (ustadz Dindin); terbimbing (para santri); metode yang dipakai yaitu bandungan dan sorogan dan terakhir adalah media yaitu pena (alat tulis), buku, serta kitab kajian berupa kitab kuning dengan judul tijan addarory fi syarbil badjury karangan Syeh Nawawi Al-Jawi.

Kedua, Hasil yang diperoleh dari bimbingan keagamaan serta motivasi yang dilakukan oleh pembimbing dalam hal ini ustadz Dindin untuk meningkatkan pemahaman ketauhidan remaja di pondok pesantren Tanjung Salam Ciwidey, bahwa sebelum diadakan bimbingan pemahaman tentang ketauhidan yang dimiliki oleh santri pondok pesantren Tanjung Salam pada awalnya hanya sebatas mengetahui sifat- sifat wajib dan mustahil bagi Allah SWT; sifat jaiz bagi Allah SWT; sifat wajib dan mustahil bagi para Rasul Allah SWTdan juga jaiz bagi Rasulullah SAW namun, setelah diadakan bimbingan mereka akhirnya dapat mengerti konsep dari ketauhidan yang telah disebutkan diatas lalu dengan secara sadar dapat mengambil pelajaran dan contoh sari sifat-sifat tersebut dan mengaplikasikannya dalam kehidupan sehari-hari. Terlihat dari penjelasan barusan bahwa santri akhirnya dapat dengan baik paham akan apa yang diberikan oleh pembimbing terlihat dari antusias serta bagaimana santri di pondok pesantren Tanjung Salam melakukan aktivitas sehari-harinya.

\section{DAFTAR PUSTAKA}

A la, Abd. (2006). Pembaruan Pesantren. Yogyakarta: Pustaka Pesantren.

Arifin, dan Kartikawati, (1995). Materi Pokok Bimbingan dan Konseling, Jakarta:

Direktorat Jenderal Pembinaan Kelembagaan Agama Islam.

Aunur, R.F., (2001). Bimbingan dan Konseling dalam Islam, Yogyakarta: UII Press.

Faiqoh. (2003). Pondok Pesantren dan Madrasah Diniyah. Jakarta: Departemen Agama

RI Direktorat Jenderal Kelembagaan Agama Islam.

Haryanto, S. (2012). Persepsi Santri Terbadap Perilaku Kepemimpina Kiai Di Pondok Pesantren. Pasuruan: Kementrian Agama RI. 
N. Khirzani., D. I. Effendi., A. Mujib.

Jazuli, S. (2016). Pendidikan Karakter : perspektif Tafsir Al-Misbach dan Kitab Shabih Bukhari dan Shabih Muslim, Banjarmasin: IAIN Antasari.

Fadlillah, M. \& Lilif Mualifatu. (2013). Pendidikan Karakter Anak Usia Dini: Konsep dan Aplikasinya Dalam PAUD. Yogyakarta: Kencana Prenada Media Group.

Nawawi al-Jawi, M. T. (1996). Tîjān al-Darāry (abad 13H). Semarang: Pustaka al"Alawiyah.

Marlina, E. (2012). Motivasi Berpuasa Ramadhan dan Moralitas Remaja dalam Ilmu Dakwah: Academic Journal for Homiletic Studies, 6 (2), 250-265.

Mufidah, L.I. (2015). Pentingnya Psikoterapi Agama dalam Kehidupan di Era Modern dalam JURNAL LENTERA : Kajian Keagamaan, Keilmuan dan Teknologi, 1(2), 182-196.

Rahim, M.A. (2006). Sepuluh teknik membangun motivasi Optimalisasi Ramadhan. Jakarta: Antar Kota.

Rusmalita, S. (2015). Metode Dakwah Untuk Lansia dalam AL-HIKMAH : Jurnal Dakwah, 9(2), 125-145.

Yarrantawie, A. (2014). Sejarah Kitab Tijan al-Darary fi syarbil badjury, diakses pada 20 Maret 2018, dari http://aladamyarrantawie.blogspot.com. 